\title{
Ordovician Meiklejohn carbonate mound, Nevada
}

SIR - In a recent number of this journal (114 (4), 1977, pp. 308-11) Dr Robin Bathurst published a useful discussion on the origin and sedimentological significance of stromatactis and of 'zebra rock' in connection with a critical review of a paper on the Ordovician Meiklejohn carbonate mound in Nevada (Ross, Jaanusson \& Friedman, 1975). Much of Bathurst's discussion is centred around the origin of the spar in the 'zebra rock' which was treated in the publication by R. J. Ross, Jr. However, he remarks also on some controversial points which have an implication to the diagenesis of the Meiklejohn carbonate mound in general, and to that of similar mounds elsewhere, and I would like to comment on these points.

The remark on the limitations of the old Grabau classification, compared with the greater precision of the more informative modern terminology of limestones by Folk or Dunham, must be due to some misunderstanding. A limestone is normally composed of a mixture of many components, such as skeletal grains, sparry calcite. micrite. terrigenous mud, etc., and the proportions between the constituents vary continuously within wide limits. The primary information that is needed for classifying a limestone is its volumetric composition with regard to the main constituents. These data are given in the paper (Ross et al. 1975, pp. 9. 11, and table 1). The second step is, based on such data, to determine the limestone type according to some classification. Several classifications are possible, such as based on grain size, proportions of dominant components or even depositional texture. In the paper a classification based mainly on grain size was preferred. following that used by Jaanusson $(1952,1972)$, in which the boundary between calcilutites and calcarenites is drawn at about $20 \%$ of skeletal sand grains, defined as equal to or larger than $0.1 \mathrm{~mm}$ in thin section. This should perhaps have been emphasised in the text. In the mound core the average content of skeletal sand is $7.5 \%$ and in the zebra limestone $3 \%$. In order to apply the classification by Folk (1959), possibly about $1 \%$ must be added for skeletal grains in the size range between 0.04 and $0.1 \mathrm{~mm}$ for which reliable volumetric data are difficult to obtain from thin sections (Jaanusson, 1972). In Folk's classification the rock would then be a fossiliferous micrite and not biomicrite as stated by Bathurst. Dunham's classification is frequently difficult to use in the practice because whether the grains were grain-or mud-supported is a matter of deduction.

My manuscript was submitted in February 1973 - before Kendall \& Tucker's (1973) paper was available - and this explains why I did not cite this important paper. The conclusion that the radiaxial calcite is mainly a replacement of an earlier fabric was arrived at independently and is based on a different set of criteria.

Bathurst emphasizes that, since the radiaxial calcite is derived from an in situ replacement of a pre-existing radial-fibrous precursor, it inherited the host surfaces, either free surfaces of skeletal grains or free walls of cavities, that were essential for the development of the precursors of any radiaxial calcite. He finds replacement of skeletal grains or fine-grained sediment by a radiaxal mosaic unlikely because they lack such controlling surfaces from which the crystals of the precursor of the radiaxial calcite could start to grow.

If we first confine the discussion to cases where the precursor of a radiaxial calcite formed a cavity-filling, then the arguments given by Bathurst are relevant up to a certain stage in the diagenesis of the rock. The diagenesis of many radiaxial mosaics stops at this stage. However, after free cavity walls and free surfaces of skeletal grains, projecting or transported into the cavity, had become lined with the crystals - according to the principles emphasized by Bathurst - the diagenetic processes continued in many limestones which contain stromatactis. There exist numerous examples showing that subsequently the radiaxial crystals or their precursors (at this stage it is mostly difficult to keep these generations apart) began to replace skeletal grains which formed the original base surfaces. An example is shown in Ross et al. (1975, fig. 29) where a portion of an echinoderm grain is in part replaced by crystals of radiaxial calcite. Also from other similar mounds various stages of replacement of skeletal grains by what now is radiaxial calcite are a common phenomenon. It is admittedly difficult to document convincingly such cases by black-and-white photographs, and other kinds of illustrations are probably also needed. The problem how the radiaxial crystals or their precursors induced a skeletal grain to change its crystal structure to conform with that of the adjacent mosaic is still unclear and requires further study.

Replacement of skeletal grains shows that radiaxial calcite does not occur solely as a former cavity-filling. However, radiaxial mosaic did not replace only grains of skeletal origin but demonstrably also micrite. The best proof for this does not come from the Meiklejohn Peak carbonate mound but from similar Ordovician mounds of the Siljan district, Sweden. There, for example, finely laminated micrite can be observed to have been replaced discordantly by a radiaxial mosaic of the same type as in stromatactis. The radiaxial mosaic

Geol. Mag. 115 (6), 1978, pp. 467-468. Printed in Great Britain 
could not possibly have been formed in a former cavity because traces of the lamination can be followed into the radiaxial mosaic where they occur as inclusions within radiaxial crystals. Documentation of this and other cases will be published in a forthcoming paper.

\section{References}

Bathurst, R. G. C. 1977. Ordovician Meiklejohn bioherm, Nevada. Geol. Mag. 114, 308-11.

Folk, R. L. 1959. Practical petrographic classification of limestones. Bull. Am. Ass. Petrol. Geol. 43, 1-38.

Jaanusson, V. 1952. Untersuchungen über die Korngrösse der ordovizichen Kalksteine. Geol. Fören. Förhandl. 74, 121-30.

Jaanusson, V. 1972. Constituent analysis of an Ordovician limestone from Sweden. Lethaia 5, 217-37.

Kendall, A. C. \& Tucker, M. E. 1973. Radiaxial fibrous calcite: a replacement after acicular carbonate. Sedimentology 20, 365-69.

Ross, R. J. Jr., Jaanusson, V. \& Friedman, I. 1975. Lithology and origin of Middle Ordovician calcareous mudmound at Meiklejohn Peak, southern Nevada. Prof. Pap. U.S. geol. Surv. no. 871.

Section of Palaeozoology

VALDAR JAANUSSON

Swedish Museum of Natural History

S-104 05 Stockholm 50

Sweden

28th November 1977 